\title{
RESPONSE OF TWO NEWLY DEVELOPED CORN GENOTYPE (Zea mays, L) TO SOME TRACE ELEMENTS UNDER SALT STRESS THROUGHOUT THEIR GROWTH LIFE SPANE:
}

2- Mineral constituents.

Helaly, M.N.*; A. A. Arafa* and H.F. Esmail ${ }^{\star *}$

* Agric. Botany Dept., Fac. of Agric., Mansoura Univ. Egypt.

** Crops Research Institute, Agric, Res. Center (ARC), Giza, Egypt.

\begin{abstract}
Nitrogen concentrations in the two maize cultivars were increased with an increase in salinity level up to $5.0 \mathrm{dsm}^{-1}$. The rate of increase was decreased at the highest level of salinity $\left(7.5 \mathrm{dsm}^{-1}\right)$ in cultivar (1) whereas decreased in cultivar (2). Moreover, salinity increased the concentrations of $\mathrm{Ca}^{++}, \mathrm{Mg}^{++}, \mathrm{Na}^{+}, \mathrm{SO}_{4}^{--}$and $\mathrm{Cl}^{-}$and the increase was a concentration dependent in the two cultivars studied. However, the values of cultivar (2) was found to be more than that recorded in cultivar (1) regarding total nitrogen concentrations except at $7.5 \mathrm{dsm}^{-1}$. The rate of increases in $\mathrm{Na}^{+}, \mathrm{SO}_{4}^{--}$ and $\mathrm{Cl}^{-}$was found to be higher than those of $\mathrm{Ca}^{++}$and $\mathrm{Mg}^{++}$as their presence in the media.

On the other hand, $\mathrm{P}$ and $\mathrm{K}$ as well as $\mathrm{Zn}, \mathrm{Fe}$ and $\mathrm{Mn}$ concentrations showed a decrease in the two maize cultivars with an increase in salinity level. The values of these elements were found to be higher in cultivar (1) than in cultivar (2) during the two growing seasons.

Application of $\mathrm{Zn}$, Fe and $\mathrm{Mn}$ increased their concentration occupied by an increase in $\mathrm{N}, \mathrm{P}, \mathrm{SO}_{4}^{--}$and $\mathrm{K}$ concentrations in the two maize cultivars grown in both growing seasons overall salinity levels. Under salinity, these elements showed an additive effect to salinity on increasing $\mathrm{N}$ and $\mathrm{SO}_{4}^{--}$concentrations whereas counteracted the depressing effect of salinity on $\mathrm{P}$ and $\mathrm{K}$ as well as their concentrations was recorded with Calcium, $\mathrm{Mg}^{++}, \mathrm{Na}^{+}$and $\mathrm{Cl}^{-}$.

Keywords: Corn, maize, salinity, trace-elements, N,P,K, Fe, Zn, Mn, $\mathrm{Ca}^{++}, \mathrm{Mg}^{++}, \mathrm{Na}^{+}$, $\mathrm{Cl}^{-}, \mathrm{SO}_{4}-\mathrm{cv} 1$ (Bachaier 13) and cv2 (Watania 4).
\end{abstract}

\section{INTRODUCTION}

The productivity of corn, such as any plant, is limited by the genotypes and influenced by the environmental conditions especially soil properties, water supply, fertilizers uses efficiency and others.

Salinity is one of the formidable problematic features of the agricultural soil in Egypt. Reclamation of such salt affected areas by the classic way implying drainage and leaching is often expensive and/or impractical.

A second more rewording approach to solve this problem would be the looking for ways and means to improve crop production from salt affected soils. This may be accomplished through the introduction of new salt tolerate varieties and/or to improve the salt tolerance capacities of some existing varieties. Plants grown on salt stresses usually suffer from several nutritional disturbances and nutrient deficiencies, especially these concerning micro- 
nutrients. These factors, together, focused the attention on plant species, and cultivars better adapted to such condition.

Many attempts were made to increase salt tolerance of plants by soaking of seeds in salt solution or microelements solution, also by application directly to plants either as foliar spray or soil application.

It is well establishment that, several micronutrients are essential for higher plants. They participate in many biochemical processes occurring in cells. Also, it was found that, application of micronutrients to field crops, a quite obtained increase in both quantity or quality of their yield.

It was found that fertilization minimize the hazardous effects of salinity on plant growth and its yield. Many investigators suggested that increasing fertilization may overcome some of the inhibitory effects of salinity. The interaction between soil fertility, salinity and cultivated crops are of major interst in optimizing crop growth and production under saline condition (Magelhaes et al., 2000).

The present investigation aimed to search for some easily applicable inexpensive treatments which would improve the salinity tolerance capacity of two new corn, Zea mays L. cultivars including single and three way cross (TWC). The fertilization effects with $\mathrm{Fe}, \mathrm{Zn}$ and $\mathrm{Mn}$ each alone or in combination either as a spraying or as a soil feeding with the recommended NPK fertilizers according to ARC, Egypt were examined on mineral constituents of the two corn; Zea mays, L. cultivars grown under saline conditions.

\section{MATERIALS AND METHODS}

Pot experiments $40 \mathrm{~cm}$ inner diameter were designed in the greenhouse at the Agricultural Botany Department, Faculty of Agriculture, Mansoura University, Egypt during the two growing seasons of 2002and 2003.

The mechanical and chemical analyses of the soil used was carried out as described by Jackson (1973) and Page et al (1982) and presented in Table (1).

Table (1):The physiochemical properties of the soil used during the two growing seasons of 2002 and 2003.

\begin{tabular}{|c|c|c|c|c|c|c|c|c|c|c|c|}
\hline \multirow[b]{3}{*}{ Season } & \multicolumn{11}{|c|}{ 1. Mechanical analysis } \\
\hline & \multicolumn{10}{|c|}{ Soil fraction $\%$} & \multirow{2}{*}{$\begin{array}{l}\text { pH (soil } \\
\text { paste) }\end{array}$} \\
\hline & \multicolumn{2}{|c|}{ Sand (coarse+fine) } & \multicolumn{2}{|c|}{ Silt } & \multicolumn{2}{|c|}{ Clay } & \multicolumn{2}{|c|}{ Organic matter } & \multicolumn{2}{|c|}{$\mathrm{CaCO}_{3}$} & \\
\hline 2002 & \multirow{2}{*}{\multicolumn{2}{|c|}{86.02}} & 6.30 & \multicolumn{3}{|c|}{6.18} & \multicolumn{2}{|c|}{0.32} & \multicolumn{2}{|c|}{1.18} & 7.8 \\
\hline \multirow[t]{4}{*}{2003} & 86.20 & & 6.4 & & \multicolumn{2}{|l|}{6.09} & \multicolumn{2}{|c|}{0.29} & \multicolumn{2}{|r|}{1.02} & 7.9 \\
\hline & \multirow{2}{*}{\multicolumn{11}{|c|}{ 2. Chemical analysis }} \\
\hline & \multirow[t]{2}{*}{$\mathrm{EC} \mathrm{dsm}^{-1}$} & \multicolumn{3}{|c|}{ CATION (meq/l) } & & & & \multicolumn{4}{|c|}{ ANION (meq/l) } \\
\hline & & $\mathrm{Ca}^{++}$ & $\mathbf{M g}^{++}$ & \begin{tabular}{l|l}
$N$ \\
+
\end{tabular} & $\mathbf{a}^{+}$ & $\bar{K}$ & $t^{+}$ & $\mathrm{HCO}_{3}{ }^{-}$ & $\mathrm{CO}_{3}^{--}$ & $\mathrm{SO}_{4}^{--}$ & $\mathrm{Cl}^{-}$ \\
\hline 2002 & 0.36 & 0.86 & 0.61 & & 48 & 0. & 19 & 1.20 & -- & 0.34 & 0.60 \\
\hline \multirow[t]{4}{*}{2003} & 0.32 & 0.82 & 0.65 & & 53 & 0. & 14 & 1.17 & -- & 0.30 & 0.67 \\
\hline & \multicolumn{11}{|c|}{ 3. Nutrients analysis } \\
\hline & \multicolumn{7}{|c|}{ Macronutrients (mg/100 g soil) } & \multicolumn{4}{|c|}{ Micronutrients (ppm) } \\
\hline & $\mathbf{N}$ & $\mathbf{P}$ & $\mathbf{K}$ & $\mathbf{C a}$ & $\mathbf{M}$ & $\lg$ & $\mathrm{Na}$ & $\mathrm{Fe}$ & Mn & $\mathrm{Zn}$ & $\mathrm{Cu}$ \\
\hline 2002 & 7.62 & 0.62 & 6.50 & 24.00 & 22 & 2.1 & 30.2 & 2.79 & 3.10 & 0.62 & 0.41 \\
\hline 2003 & 8.00 & 0.50 & 6.44 & 25.10 & 21 & 1.7 & 32.5 & 3.10 & 3.02 & 0.54 & 0.50 \\
\hline
\end{tabular}


Four levels of artificial sea water were used by dissolving known weight of natural salt crust, in tape water. The natural salt crust was brought directly from the salterns of Rashid, El-Beheira Governorate, Egypt. The four salinity levels: Tap water $\left(0.36 \mathrm{dsm}^{-1}\right), 2.5,5$ and $7.5 \mathrm{dsm}^{-1}$ denoted control, low, high and highest levels, respectively. To obtain 4 levels of soil salinity, EC of the pots media was measured in soil past extract (SPE) and soluble salts percentages (SSP) were calculated from the equation of Richard's (1954) as follows:

$$
\mathrm{SSP}=\frac{\mathrm{EC} \mathrm{dsm}^{-1} \times 0.64}{1000} \times \frac{}{\text { saturation percentage }(\mathrm{SP})}
$$

The amount of salt for each salinity level was calculated, dissolved in the proper amount of tap water and used for irrigation.

Chemical analyses of the natural salt crust used for salinization were determined according to the standard procedures described by Piper (1950) and Jackson (1973) and the composition of the four salt solutions are presented in Table (2).

Table (2): Chemical composition analyses of the natural salt crust used for salinization (meq/100g) and the four salinity levels used (meq/l).

\begin{tabular}{|c|c|c|c|c|c|c|c|c|c|c|}
\hline \multicolumn{11}{|c|}{$\begin{array}{r}\text { 1. Chemical composition analy } \\
\text { saliniz }\end{array}$} \\
\hline \multicolumn{5}{|c|}{ CATION (meq/l) } & \multicolumn{6}{|c|}{ ANION (meq/l) } \\
\hline $\mathrm{Ca}^{++}$ & $\mathbf{M g}^{++}$ & $\mathrm{Na}^{+}$ & \multicolumn{2}{|c|}{$\mathbf{K}^{+}$} & $\mathrm{HCO}_{3}^{-}$ & $\mathrm{CO}_{3}^{--}$ & & $\mathrm{SO}_{4}^{--}$ & \multicolumn{2}{|c|}{$\mathrm{Cl}^{-}$} \\
\hline 40.92 & 54.11 & 1500.0 & \multicolumn{2}{|c|}{4.98} & 10.94 & & \multicolumn{2}{|c|}{148.35} & \multicolumn{2}{|c|}{1440.72} \\
\hline \multicolumn{10}{|c|}{ 2. Chemical composition analyses of the four salinity levels used } & \\
\hline \multirow{2}{*}{\multicolumn{2}{|c|}{$\begin{array}{c}\text { Salinity levels } \\
\text { used }\end{array}$}} & E.C & \multicolumn{4}{|c|}{ Caons (meq/l) } & \multicolumn{4}{|c|}{ Anions (meq/l) } \\
\hline & & dsm $^{-1}$ & $\mathrm{Ca}^{++}$ & $\mathbf{M g}^{++}$ & $+\mathrm{Na}^{+}$ & $\mathbf{K}^{+}$ & $\mathrm{HCO}_{3}{ }_{3}$ & $\mathrm{CO}_{3}{ }_{3}$ & $\mathrm{SO}_{4}$ & $\mathrm{Cl}^{-}$ \\
\hline Control & & 0.36 & 0.34 & 0.35 & 1.21 & 0.14 & 0.57 & -- & 0.22 & 1.25 \\
\hline Low & & 2.5 & 0.50 & 0.75 & 26.2 & 0.16 & 0.80 & -- & 14.0 & 12.8 \\
\hline High & & 5.0 & 0.75 & 1.24 & 50.63 & 0.18 & 1.28 & -- & 26.49 & 25.02 \\
\hline Highest & & 7.5 & 0.91 & 1.70 & $76.25 \mid$ & 0.21 & 1.28 & -- & 40.01 & 37.78 \\
\hline \multicolumn{11}{|c|}{$\begin{array}{l}\text { 3. Salt composition ( } \mathrm{g} / 100 \mathrm{~g} \text { salt) of the salt crust used in irrigation water } \\
\text { salinization process }\end{array}$} \\
\hline \multicolumn{2}{|c|}{$\mathrm{Ca}\left(\mathrm{HCO}_{3}\right)_{2}$} & $\mathrm{CaSO}_{4}$ & \multicolumn{2}{|c|}{$\mathrm{K}_{2} \mathrm{SO}_{4}$} & \multicolumn{2}{|c|}{$\mathrm{MgSO}_{4}$} & \multicolumn{2}{|c|}{$\mathrm{Na}_{2} \mathrm{SO}_{4}$} & \multicolumn{2}{|c|}{$\mathrm{NaCl}$} \\
\hline \multicolumn{2}{|c|}{0.888} & 2.040 & \multicolumn{2}{|c|}{0.425} & \multicolumn{2}{|c|}{3.247} & \multicolumn{2}{|c|}{4.216} & \\
\hline
\end{tabular}

Before sowing, each pot in the two growing seasons was fertilized with $2 \mathrm{~g}$ calcium superphosphate; $15 \% \mathrm{P}_{2} \mathrm{O}_{5}$ (200 kg/fed). Potassium sulphate; 48 $\% \mathrm{~K}_{2} \mathrm{O}$ and Ammonium nitrate; $33.5 \% \mathrm{~N}$ were used for potassium and nitrogen fertilization at the rate of 100 and $150 \mathrm{~kg} / \mathrm{fed}$, respectively i.e. $1.4 \mathrm{~g}$ from the former and $5.0 \mathrm{~g}$ from the later per pot in two equal portions. The first portion was added 20 days after sowing and the second at 30 days later. So, the recommended fertilization dose was $130 \mathrm{~N}+48 \mathrm{~K}_{2} \mathrm{O}+30.0 \mathrm{P}_{2} \mathrm{O}_{5}$ unit/feddan according to the Agriculture Research Center; ARC, Ministry of Agric., Egypt. Two cultivars of corn were used in these seasons. Corn grains of the two cultivars were obtained from the local hybrids which registered by 
Agricultural Research Center (ARC), Ministry of Agriculture, Egypt. The two cultivars chosen were one from the single hybrid (Bachaer 13) and the other from TWC hybrid (TWC 310) namely cv (1) and cV (2) respectively. The obtained corn grains were sterilized by dipping successively into mercuric chloride $(0.001 \%)$ and aqueous ethanol $(70 \%)$ for two minutes each, then washed with tap water and planted. Five grains were sowed in the $1^{\text {st }} J$ une in the two growing seasons of 2002 and 2003 by distributing them uniformly in the soil at a depth of $1 \mathrm{~cm}$. The pots were watered immediately with the specific irrigation saline water treatments after sowing, and thinned to 3 plants per pot at the $17^{\text {th }}$ day from sowing; $5^{\text {th }}$ leaf stage of growth. Irrigation with the appropriate saline specific water was carried out whenever required. Other usual cultural practices of maize cultivation were carried out according to those recommended by the Ministry of Agriculture, Egypt.

Enough amounts of the specific irrigation water were added to bring the moisture content well over saturation capacity which had previously determined.The accumulation of salts on the media were leached out once every two irrigations using enough amount of the specific saline water calculated according to the following equation (Richard's, 1954).

Leaching Requirements (L.R.) $=\mathrm{D}_{\mathrm{dw}} / \mathrm{D}_{\mathrm{iw}}=\mathrm{EC}_{\mathrm{iw}} / \mathrm{EC} \mathrm{dw}$

Where:

$D_{d w}$ and $D_{\text {iw }}$ represent the equivalent depth of drainage and depth of irrigation water

$\mathrm{EC}_{\mathrm{iw}}$ and $\mathrm{EC}_{\mathrm{dw}}$ represent the electric conductivity of the irrigation and drainage water, respectively.

The pots in each saline level were thoroughly leached with sufficient amounts of the desired saline solution to salinize the growth media with the specific examined level as well as to reach the soil at saturation and to yield the required level of salinity. The salinization process was done at a month before corn grains sowing in both seasons to reach the soil at equilibrium. The following different treatments were chosen as easily applicable inexpensive treatments which would improve the salt tolerance capacity of the two cultivars under the previous four salinity levels.

1- Control plants: Plants were treated twice with distilled water during the early vegetative growth period; the $1^{\text {st }}$ after 20 and the $2^{\text {nd }}$ at 30 days from sowing.

2- Plants were sprayed twice with either of $\mathrm{Zn}, \mathrm{Mn}$ and /or $\mathrm{Fe}$ at the recommended rates as obtained from the promising treatments of the preliminary experiments. Spraying took place twice till dripping during the vegetative growth period; after 20 and 30 days from sowing. The traceelements chosen at the recommended doses were used alone or in combinations and supplemented with $0.025 \%$ Tween 20 solution as a wetting agent.

3- Plants were fertilized by soil feeding with the former trace-elements used at the same doses in two equal portions at 20 and 30 days after sowing supplemented with the specific salinized-irrigation water.

Micronutrients; Foliafeed zinc 15\% chelated (EDTA), Foliafeed chelated manganes $15 \%$ and Folifeed chelated iron $13 \%$ registration numbers 1890, 1891 and 1892, respectively by the Ministry of Agriculture, 
Egypt were used. Foliafeed micronutrients produced by Advanced Agrochemicals Co., New Nubariya City, Egypt. The recommended rate by the preliminary experiments of the present investigation $(250 \mathrm{~g}$ from each powder /feddan) were used.

Each treatment was replicated 8 times. Four of them were kept till the end of the experimental period and used for the morphological and growth characters. The pots were arranged in a factorial complete randomized block design system.

\section{Sampling dates and data recorded:}

Plant samples were taken from each treatment of the two cultivars used for growth parameters at 35, 65 and 115 days from sowing coincided as best as possible with the following physiological stages: 10 leaved plants, tasseling and harvesting.

Total nitrogen was determined in the shoots dried material using the modified micro keldahl apparatus of Parnas and Wagner as described by Jones et al (1991).

For other minerals determinations, $0.5 \mathrm{~g}$ of the crude dried shoots from each sample was wet digested with a mixture of concentrated sulphuric acid and perchloric acid, then heated until become clear solution (Peterburgski, 1968). After digestion, the cleared solution was quantitatively transferred into $100 \mathrm{ml}$ flask with distilled water and kept for determinations. Phosphorus was determined spectrophotometrically by Milton Roy Spectronic 1201 at wave length $725 \mu \mathrm{m}$ using stannous chloride reduced molybdophosphoric blue colur method in sulphoric acid system as described by Jackson (1973). Potassium and sodium were estimated flamephotometrically using Jenway Flamephotometer (Peterburgski, 1968). Calcium, magnesium as well as micronutrients of zinc, manganese and iron were determined in the digestive extract by using the Atomic Absorption Spectrophotometer GBC, 932, AA. Dry ashing at $550-650{ }^{\circ} \mathrm{C}$ was prepared for chloride and sulphate determination (Chapman and Pratt, 1961). Chloride was determined in the extract of dry ashing by titration with silver nitrate. Total sulphate in the plant samples were estimated by using dry ashing-barium method (Jackson, 1973).

The analysis of variance was done in the present investigation as regular two way classification out-lined by Gomez and Gomez (1984). F-test was used for significance. Salinity, treatments and their interactions were tested against the error variance (salinity $x$ treatments). If the $F$ value foe entries is found to be significant the LSD (Least Significant Difference) at 5\% of probability was considered a valid least for the above planned comparisons of means.

\section{RESULTS AND DISCUSSION}

Data in Table( 3 )show that $\mathrm{N}$ concentrations in the shoots of the two maize cultivars grown in the two growing seasons were increased with an increase in salinity level up to $5.0 \mathrm{dsm}^{-1}$. The rate of increase was decreased at the highest level of salinity $\left(7.5 \mathrm{dsm}^{-1}\right)$ in the shoots of cultivar (1) whereas decreased in the shoots of cultivar (2). The increase in total $\mathrm{N}$ concentrations under salinity may be, in part, due to the limited utilization of $\mathrm{N}$-substances 
and consequently their accumulation is more rapid than their utilization for the formation of new cells and tissues (Helaly, 1977). Moreover, it could be mentioned that values of cultivar (2) was found to be more than that recorded in cultivar (1) regarding total nitrogen concentrations except at $7.5 \mathrm{dsm}^{-1}$. The disturbances in nitrogen metabolism may occur in plants grown under salinity and therefore soluble- $\mathrm{N}$ fraction may increase especially in the more sensitive plants such as cultivar (2). It could be pointed out that the increase in $\mathrm{N}$ concentrations in the shoots of the two corn cultivars grown under salinization in together with an inhibition in shoot growth have occurred due to the effect of salinity on growth rather than $\mathrm{N}$ uptake. The decline noticed in $\mathrm{N}$ concentration in maize shoots of cultivar (2), more sensitive, may be due to the disturbances in the cation balance, particularly the abundance of sodium which, in turn, cause disturbances in protein and nucleic acid metabolism (Helaly et al., 1985 a\&b). Pessaraki (2002) added that the reduction in $\mathrm{N}$ uptake under saline condition may be due to the reduction in water absorbed and a decreased in root permeability.

The concentrations of $\mathrm{P}$ and $\mathrm{K}$ (Table 3 ) as well as $\mathrm{Zn}, \mathrm{Fe}$ and $\mathrm{Mn}$ ( Table 6) showed a decrease whereas those of $\mathrm{SO}_{4--}^{-}$and $\mathrm{Cl}^{-}$showed an increase in the two maize cultivars with an increase in salinity level. The values of these elements were found to be higher in cultivar (1) than in cultivar (2) during the two growing seasons. The decline in $\mathrm{P}$ and $\mathrm{K}$ concentrations due to salinity may be attributed to $\mathrm{Na}^{+}$, the main cation of the natural salt crust used for salinization process, substitution mechanisms for one or more of these mineral and/or an antagonistic state between $\mathrm{Na}$ and one or more of the nutrients present in the growth media (Sharma, 1995 a \& b and Sharma, 1996). In this context, Salem et al. (2002) reported that the decrease in $\mathrm{K}^{+}$concentration under saline condition may be attributed to the antagonism between $\mathrm{K}^{+}$and $\mathrm{Na}^{+}$cations which increased considerably as salinity increased. Helay (1977) reported that salinity depressed the availability of $P$ and lowering the activation of its uptake. He added that, salinity seems to achieve an extra degree in the fixation of $P$ added as a fertilizer. There is a good evidence for hormonal regulation of ion uptake by plant cells under salinity. Helay et al., 1984 a \& b). Rengel (1999) attributed the decrease in $\mathrm{P}$ concentrations to the higher $\mathrm{pH}$ values of $\mathrm{Na}^{+}$affected soils in which hinder $P$ availability to plants or due to the harmful effects of salinity that cause release of some membrane proteins required for uptake and active transport of this element in the roots (Pessaraki, 2002).

On the other hand, it was found that application of $\mathrm{Zn}, \mathrm{Fe}$ and $\mathrm{Mn}$ increased $\mathrm{N}, \mathrm{P}, \mathrm{SO}_{4}^{--}$and $\mathrm{K}$ as well as $\mathrm{Zn}, \mathrm{Fe}$ and $\mathrm{Mn}$ concentrations(Table 6 ) in the two maize cultivars grown in the both growing seasons overall salinity levels. Regarding plants grown under salinity, it was found that traceelements showed an additive effect to salinity on increasing $\mathrm{N}$ and $\mathrm{SO}_{4}$ concentrations and counteracted the depressing effect of salinity on $\mathrm{P}$ and $\mathrm{K}$ as well as $\mathrm{Zn}, \mathrm{Fe}$ and $\mathrm{Mn}$ concentrations. The role of $\mathrm{Zn}$ on hormonal biosynthesis was previously reported (Wilkinson, 1994). The hormonal modification under the influence of trace elements was partially overcomes the disturbances caused by salinity on $\mathrm{N}, \mathrm{P}$ and $\mathrm{K}$ concentrations. In this context, El-Emary (2005) found that $\mathrm{Zn}, \mathrm{Mn}$ and Fe treatments increased 
absorption of $\mathrm{N}, \mathrm{P}$ and $\mathrm{K}$ as well as $\mathrm{Zn}, \mathrm{Mn}$ and $\mathrm{Fe}$ in sugar beet plants growing in different sites of Kafr El-Sheikh governorate, Egypt.

Regarding the interaction effects of salinity and trace-elements on $\mathrm{Ca}^{++}, \mathrm{Mg}^{++}, \mathrm{Na}^{+}\left(\right.$Table 4) and $\mathrm{Cl}^{-}$as well as $\mathrm{Zn}, \mathrm{Mn}$ and Fe concentrations, data in the same tables( Tables 4\&6) showed that salinity increased the concentrations of all these elements in the shoots of the two cultivars of maize during the two growing seasons. The values of these elements in cultivar (2) was found to be more than those recorded in cultivar (1), more resistance cultivar. The rate of increases in $\mathrm{Na}^{+}, \mathrm{SO}_{4}^{--}$and $\mathrm{Cl}^{-}$was found to be higher than those of $\mathrm{Ca}^{++}$and $\mathrm{Mg}^{++}$as their presence in the media. Taiz and Zeiger (1991) postulated that $\mathrm{Mg}^{++}$concentration in the chloroplasts may influence photosynthesis during stress through its role in coupling electron transport to ATP production. The plants with the low $\mathrm{Mg}^{++}$concentration maintained higher photosynthetic rates as leaves become hydrate. Pessaraki (1994) indicated that $\mathrm{Ca}^{++}$is strongly competitive with $\mathrm{Mg}^{++}$and binding sites on the root plasma membrane appear to have less affinity for the highly hydrated $\mathrm{Mg}^{++}$than for $\mathrm{Ca}^{++}$. Thus high concentration of substrate $\mathrm{Ca}^{++}$ usually result in increased leaf $\mathrm{Ca}^{++}$along with a marked reduction leaf $\mathrm{Mg}^{++}$. Moreover, the presence of sufficient $\mathrm{Ca}^{++}$in saline solution is essential to prevent the accumulation of toxic levels of $\mathrm{Na}^{+}$, because $\mathrm{N}$ uptake by plants is strongly regulated by $\mathrm{Ca}^{++}$in the growth media.

The increase in $\mathrm{Na}^{+}, \mathrm{SO}_{4}^{--}$and $\mathrm{Cl}^{-}$as well as $\mathrm{Zn}, \mathrm{Fe}$ and $\mathrm{Mn}$ was a concentration dependent as a result of their present in the growth media and enhanced the free diffusion of these ions through cells of the root system (Janes, 1966).

The high concentrations of $\mathrm{Mg}^{++}, \mathrm{Ca}^{++}, \mathrm{Na}^{+}, \mathrm{SO}_{4}^{--}$and $\mathrm{Cl}^{-}$under saline condition suggested that under saline condition their influx, especially $\mathrm{Na}^{+}$, across the plasmalemma to the vacuole was play a major role in permitting turgor maintenance. Some crops show marked beneficial effects of $\mathrm{Na}^{+}$if the $\mathrm{K}^{+}$supply is limited. These crops take up large amounts of $\mathrm{Na}^{+}$which contribute to the osmotic potential of the leaves and increases resistance to water stress. In wheat, it was found that its yield was responded to $\mathrm{Na}^{+}$often exceeds that of $\mathrm{K}^{+}$(Ghallab and Nesiem, 1999).

Plants treated with trace element showed an increase in $\mathrm{Zn}, \mathrm{Fe}$ as well as $\mathrm{Mn}$ and a decrease in the concentrations of $\mathrm{Mg}^{++}, \mathrm{Na}^{+}, \mathrm{SO}_{4^{--}}$and $\mathrm{Cl}^{-}$, whereas, $\mathrm{Ca}^{++}$was not affected significantly. These results are true overall salinity levels of the two cultivars studied during the two growing seasons. In the presence of salinity, it was found that trace-element treatments minimized the increase of $\mathrm{Na}^{+}, \mathrm{SO}_{4--}^{--}$and $\mathrm{Cl}^{-}$absorption which recorded by salinity. The ratio of $\mathrm{K}^{+} / \mathrm{Na}^{+}$was gradually decreased as the salinity level increased whereas $\mathrm{Na}^{+} / \mathrm{Ca}^{++}$ratio exhibited an increase. Similar results were reported by El-Emary (2005) on sugar beet.

It appears that trace-elements play a role in the regulation of ions uptake in maize grown under salinity especially with more resistance cultivars. Trace element may also modify the movement of nutrients within the plants causing adaptation of the nutritional requirements under salinity (Hatung, 2004). Wilkinson (1994) reported that under saline condition $\mathrm{Na}^{+}$ has important specific effects. Both $\mathrm{Na}^{+}$and $\mathrm{K}^{+}$will move along the 
electrochemical gradients of tissues but because of either discrimination of the cell membranes or $\mathrm{Na}^{+}$extrusion, the ultimate concentration ratio my be $20 \mathrm{~K}^{+}$to $1 \mathrm{Na}^{+}$. He added that growth of beans was markedly influenced by its recorded increase in $\mathrm{Na}^{+} / \mathrm{Ca}^{++}$at high $\mathrm{NaCl}$ salinity level. Growth of beans decreased and $\mathrm{Na}^{+}$increased in the external only when $\mathrm{N}^{+} / \mathrm{Ca}^{++}$exceeded. Increase in membrane permeability due to the high $\mathrm{Na}^{+} / \mathrm{Ca}^{++}$is the primary cause of these response. On wheat plants, Nuttall et al. (2003) found that when the $\mathrm{K} / \mathrm{Na}^{+}$ratio was 2.5 adverse effects of salinity could be expected. $\mathrm{K}^{+} / \mathrm{Na}^{+}$ratio 1.5 is corresponding to $50 \%$ reduction in growth.

Data in the same tables( Tables( $4 \& 5$ and 6) showed that raising salinity level resulted in disorder in the nutritional status of the two cultivars corn plants and this was reflected on dry matter accumulation. The ratios of $\mathrm{N} / \mathrm{Na}, \mathrm{P} / \mathrm{Na}, \mathrm{K} / \mathrm{Na}, \mathrm{N} / \mathrm{Cl}, \mathrm{P} / \mathrm{Cl}, \mathrm{K} / \mathrm{Cl}, \mathrm{SO}_{4} / \mathrm{Cl}, \mathrm{Fe} / \mathrm{Na}, \mathrm{Zn} / \mathrm{Na}, \mathrm{Mn} / \mathrm{Na}, \mathrm{Fe} / \mathrm{Cl}$, $\mathrm{Zn} / \mathrm{Cl}$ and $\mathrm{Mn} / \mathrm{Cl}$ (data not presented) were decreased due to salinity whereas $\mathrm{SO}_{4} / \mathrm{Fe}$ was increase. Trace-elements treatments affected on these ratios by restoring the balance between each nutrient and others. It is well known that each nutrients (macro or micro) has an essential physiological role in plant metabolism, which is well achieved at their balance. The basis of balance, in the present investigation, dependent on the comparative studies between the recorded ratios in the treatment and its corresponding control.

Table 3: Effect of salinity, some trace elements $(\mathrm{Zn}+\mathrm{Mn}+\mathrm{Fe})$ and their interaction on the concentration ( $\mathrm{mg} / \mathrm{g} \mathrm{D}$.Wt.) of $\mathrm{N}, \mathrm{P}, \mathrm{K}$ during 2002 and 2003 seasons.

\begin{tabular}{|c|c|c|c|c|c|c|}
\hline \multirow{2}{*}{\begin{tabular}{|l|} 
Characters \\
Treatments
\end{tabular}} & \multicolumn{2}{|c|}{$\mathbf{N}$} & \multicolumn{2}{|c|}{$\mathbf{P}$} & \multicolumn{2}{|c|}{ K } \\
\hline & 2002 & 2003 & 2002 & 2003 & 2002 & 2003 \\
\hline \multicolumn{7}{|l|}{ A- Cultivars: } \\
\hline $\mathrm{C} 1$ & 2.98 & 3.14 & 2.98 & 2.67 & 15.82 & 16.29 \\
\hline $\mathrm{C} 2$ & 2.48 & 3.13 & 2.24 & 2.29 & 15.60 & 15.47 \\
\hline F-test & * & * & $* *$ & $* \star$ & NS & NS \\
\hline \multicolumn{7}{|c|}{ B- Salinity levels (dsm ${ }^{-1}$ ) } \\
\hline Control & 2.43 & 2.60 & 2.45 & 2.56 & 15.60 & 15.73 \\
\hline 2.5 & 2.50 & 2.65 & 2.40 & 2.51 & 15.51 & 15.65 \\
\hline 5.0 & 3.05 & 2.68 & 2.83 & 2.46 & 15.92 & 16.10 \\
\hline 7.5 & 2.94 & 3.12 & 2.78 & 2.41 & 15.80 & 16.03 \\
\hline F-test & * & * & * & $\star *$ & * & * \\
\hline LSD at $5 \%$ & 0.01 & 0.02 & 0.11 & 0.08 & 0.04 & 0.05 \\
\hline \multicolumn{7}{|l|}{ C- Treatments: } \\
\hline Control & 2.45 & 2.62 & 2.34 & 2.45 & 15.40 & 15.58 \\
\hline Trace element & 3.01 & 3.15 & 2.89 & 2.52 & 16.02 & 16.18 \\
\hline F-test & $\star *$ & * & $*$ & $*$ & * & * \\
\hline \multicolumn{7}{|l|}{ E- Interactions: } \\
\hline$A \times B$ & * & * & * & * & * & * \\
\hline$A \times C$ & * & * & ** & * & * & * \\
\hline $\mathrm{B} \times \mathrm{C}$ & * & ** & * & * & * & * \\
\hline$A \times B \times C$ & ** & * & * & ** & ** & * \\
\hline
\end{tabular}


Table 4: Effect of salinity, some trace elements $(Z n+M n+F e)$ and their interaction on the concentration (mg/g D.Wt.) of $\mathrm{Ca}, \mathrm{Mg}, \mathrm{Na}$ during 2002 and 2003 seasons.

\begin{tabular}{|c|c|c|c|c|c|c|}
\hline \multirow{2}{*}{\begin{tabular}{|} 
Characters \\
Treatments
\end{tabular}} & \multicolumn{2}{|c|}{$\mathrm{Ca}$} & \multicolumn{2}{|c|}{ Mg } & \multicolumn{2}{|c|}{$\mathrm{Na}$} \\
\hline & 2002 & 2003 & 2002 & 2003 & 2002 & 2003 \\
\hline \multicolumn{7}{|l|}{ A- Cultivars: } \\
\hline C1 & 18.62 & 18.70 & 2.52 & 2.77 & 8.63 & 9.42 \\
\hline $\mathrm{C} 2$ & 17.83 & 17.80 & 3.05 & 2.74 & 11.22 & 12.25 \\
\hline F-test & * & ** & * & NS & $\star \star$ & ** \\
\hline \multicolumn{7}{|c|}{ B- Salinity levels (dsm-1) } \\
\hline \begin{tabular}{|c|} 
Control \\
\end{tabular} & 17.93 & 18.01 & 2.13 & 2.41 & 9.00 & 10.24 \\
\hline 2.5 & 17.96 & 18.06 & 2.42 & 2.69 & 9.03 & 9.87 \\
\hline 5.0 & 18.24 & 18.31 & 3.08 & 2.77 & 9.75 & 10.69 \\
\hline 7.5 & 18.76 & 18.34 & 3.52 & 3.14 & 11.93 & 12.53 \\
\hline F-test & * & * & $\star *$ & $* *$ & $* *$ & $* *$ \\
\hline LSD at $5 \%$ & 0.02 & 0.01 & 0.07 & 0.21 & 0.48 & 0.64 \\
\hline \multicolumn{7}{|l|}{ C- Treatments: } \\
\hline Control & 17.93 & 18.01 & 2.95 & 2.97 & 12.67 & 13.95 \\
\hline Trace element & 18.52 & 18.59 & 2.62 & 2.53 & 7.18 & 7.72 \\
\hline F-test & * & ** & $\star *$ & $\star \star *$ & $\star \star$ & $* *$ \\
\hline \multicolumn{7}{|l|}{ E- Interactions: } \\
\hline$A \times B$ & * & NS & NS & * & *夫 & ** \\
\hline$A \times C$ & * & * & $* *$ & ** & ** & ** \\
\hline$B \times C$ & NS & NS & NS & NS & ** & ** \\
\hline$A \times B \times C$ & * & & & * & ** & ** \\
\hline
\end{tabular}

Table 5: Effect of salinity, some trace elements $(\mathrm{Zn}+\mathrm{Mn}+\mathrm{Fe})$ and their interaction on the concentration (mg/g D.Wt.) of $\mathrm{Cl}, \mathrm{K} / \mathrm{Na}$, $\mathrm{Na} / \mathrm{Cl}$ during 2002 and 2003 seasons.

\begin{tabular}{|c|c|c|c|c|c|c|c|c|}
\hline \multirow{2}{*}{$\begin{array}{c}\text { Characters } \\
\text { Treatments }\end{array}$} & \multicolumn{2}{|c|}{$\mathrm{Cl}$} & \multicolumn{2}{|c|}{$\mathrm{K} / \mathrm{Na}$} & \multicolumn{2}{|c|}{$\mathrm{Na} / \mathrm{Cl}$} & \multicolumn{2}{|c|}{$\mathrm{SO}_{4}$} \\
\hline & 2002 & 2003 & 2002 & 2003 & 2002 & 2003 & 2002 & 2003 \\
\hline \multicolumn{9}{|l|}{ A- Cultivars: } \\
\hline C1 & 12.86 & 13.69 & 0.96 & 0.96 & 0.27 & 0.29 & 3.4 & 3.9 \\
\hline $\mathrm{C} 2$ & 13.70 & 15.09 & 0.45 & 0.45 & 0.35 & 0.38 & 4.0 & 4.8 \\
\hline F-test & ** & $* *$ & * & * & $* *$ & $* *$ & $\star *$ & $\star \star$ \\
\hline \multicolumn{9}{|c|}{ B- Salinity levels (dsm $\left.{ }^{-1}\right)$} \\
\hline \begin{tabular}{|l|} 
Control \\
\end{tabular} & 10.44 & 11.56 & 0.36 & 0.38 & 0.28 & 0.32 & 1.4 & 1.6 \\
\hline 2.5 & 12.55 & 13.29 & 0.46 & 0.44 & 0.28 & 0.31 & 2.3 & 2.8 \\
\hline 5.0 & 13.28 & 14.63 & 0.70 & 0.71 & 0.30 & 0.33 & 3.2 & 3.5 \\
\hline 7.5 & 16.88 & 18.09 & 0.95 & 0.96 & 0.37 & 0.39 & 8.0 & 9.4 \\
\hline F-test & $\star *$ & $\star *$ & * & * & $* *$ & $* *$ & $\star *$ & $\star *$ \\
\hline LSD at $5 \%$ & 0.48 & 0.59 & 0.09 & 0.11 & 0.01 & 0.02 & 0.1 & 0.3 \\
\hline \multicolumn{9}{|l|}{ C- Treatments: } \\
\hline \begin{tabular}{|l|} 
Control \\
\end{tabular} & 13.96 & 15.03 & 0.45 & 0.46 & 0.40 & 0.44 & 4.2 & 4.7 \\
\hline Trace element & 12.60 & 13.76 & 0.52 & 0.63 & 0.22 & 0.24 & 3.3 & 4.0 \\
\hline F-test & $\star *$ & $* *$ & * & * & $\star *$ & ** & $\star *$ & $\star \star$ \\
\hline \multicolumn{9}{|l|}{ E- Interactions: } \\
\hline$A \times B$ & NS & NS & ** & ** & $\star \star \star$ & ** & 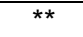 & ** \\
\hline$A \times C$ & * & $* *$ & ** & ** & ** & ** & NS & NS \\
\hline$B \times C$ & NS & NS & ** & ** & ** & ** & ** & * \\
\hline$A \times B \times C$ & & & NS & NS & ** & ** & * & * \\
\hline
\end{tabular}


Table 6: Effect of salinity, some trace elements $(Z n+M n+F e)$ and their interaction on the concentration ( $\mu \mathrm{g} / \mathrm{g}$ D.Wt.) of $\mathrm{Zn}, \mathrm{Mn}$ and $\mathrm{Fe}$ during 2002 and 2003 seasons.

\begin{tabular}{|c|c|c|c|c|c|c|}
\hline \multirow{2}{*}{$\begin{array}{c}\text { Characters } \\
\text { Treatments }\end{array}$} & \multicolumn{2}{|c|}{$\mathbf{Z n}$} & \multicolumn{2}{|c|}{ Mn } & \multicolumn{2}{|c|}{$\mathbf{F e}$} \\
\hline & 2002 & 2003 & 2002 & 2003 & 2002 & 2003 \\
\hline \multicolumn{7}{|l|}{ A- Cultivars: } \\
\hline C1 & 22.7 & 26.0 & 39.0 & 44.6 & 130.9 & 134.3 \\
\hline $\mathrm{C} 2$ & 18.6 & 19.7 & 34.4 & 35.5 & 121.8 & 123.1 \\
\hline F-test & $\star \star$ & $\star \star$ & $\star \star$ & $\star \star$ & $\star \star$ & ${ }^{* *}$ \\
\hline \multicolumn{7}{|c|}{ B- Salinity levels (dsm $\left.{ }^{-1}\right)$} \\
\hline Control & 27.0 & 27.8 & 53.8 & 58.6 & 158.4 & 158.8 \\
\hline 2.5 & 24.4 & 27.3 & 51.0 & 58.3 & 152.1 & 155.1 \\
\hline 5.0 & 21.4 & 22.3 & 26.6 & 27.3 & 124.5 & 126.0 \\
\hline 7.5 & 9.7 & 14.1 & 15.3 & 16.1 & 70.4 & 73.9 \\
\hline F-test & ** & $\star *$ & $\star *$ & $\star *$ & $* *$ & $\star *$ \\
\hline LSD at $5 \%$ & 1.1 & 0.9 & 2.2 & 1.4 & 2.9 & 2.3 \\
\hline \multicolumn{7}{|l|}{ C- Treatments: } \\
\hline Control & 19.2 & 21.6 & 36.0 & 38.9 & 124.2 & 126.8 \\
\hline Trace element & 22.0 & 24.0 & $\begin{array}{c}37.3 \\
*\end{array}$ & $\underset{* *}{41.3}$ & 128.5 & 130.6 \\
\hline \multicolumn{7}{|l|}{ E- Interactions: } \\
\hline$A \times B$ & NS & ** & ** & $\star * *$ & $\star *$ & ** \\
\hline$A \times C$ & ** & * & * & NS & NS & NS \\
\hline$B \times C$ & NS & * & NS & NS & NS & $* \star$ \\
\hline$A \times B \times C$ & * & * & * & * & * & ** \\
\hline
\end{tabular}

The positive effects of trace-elements on the nutritional status of the salt-stressed maize plant may be ascribed to overcoming the substitution occurred between $\mathrm{Na}^{+}$and $\mathrm{K}^{+}$as well as their roles as an activators of several enzymes required for plant metabolism and endogenous hormones synthesis. Enhancing $\mathrm{K}^{+}$uptake that is required for the normal metabolic processes and its role as osmotic component was previously reported (Wilkinson, 1994). Similarly the role of $\mathrm{Zn}$ on auxin biosynthesis as well as $\mathrm{Fe}$ and $\mathrm{Mn}$ on plant metabolism were reported (Vogel, 1975 and Jeffrey, 1987). Fatouh Youssef (2003) found that spraying with $\mathrm{AbA}$ inhibited $\mathrm{Na}^{+}$and accelerated the accumulations of $\mathrm{K}^{+}, \mathrm{Ca}^{++}, \mathrm{Mg}^{++}$, as well as total nitrogen and phosphorus, proline, total free amino acids and sugars in roots and shoots of salt-stressed wheat plants. Moreover trace elements are involved in important biological processes; ionic balance, DNA and RNA synthesis as well as protein stabilization which associated with cell division with active growth and metabolism (Taiz and Zeiger, 1991). The characteristics of trace elements as a stress response and its role in the cell protection against unfavorable condition and their effectiveness on alleviation of salt stress injury were previously reported and reviewed (Helaly, 1977).

\section{REFERENCES}

Chapman, H.D. and P.F. Pratt (1961). "Methods of Analyses of Soil Plants and Waters". Univ. of California press, U.S.A. pp.195.

El-Emary, F.A. (2005). Morphophosiological and anatomical studies on sugar beet plant (Beta vulgaris, L.). Ph. D. Thesis, Faculty of Agric. Kafr ElSheikh, Tanta Univ., Egypt. 
Fatouh Youssef, H. M. (2003). Physiological studies on production of wheat plants more tolerant to salinity via modern biotechnology. Ph. D. Thesis, Plant Physiol. Division, Agric. Botany Dept. Fac. Agric., Cairo Univ.,

Ghallab, A.M. and M.R.A. Nesiem (1999). Effect of Foliar application of titanium on growth, chemical composition and productivity of soybean and wheat plants growing under different levels of NPK fertilization J. Agric. Sci Mansoura Univ., 24(2): 605-623.

Gomez, K. A. and A. A. Gomez (1984). Statistical Procedures for Agriculture Research. $2^{\text {nd }}$ Ed. John Wiley and Sons. pp. 680.

Hatung, W. (2004). Plant response to stress: Abscisic acid fluxes. Marcel Dekker Inc., New York. pp. 540-690.

Helaly, M.N.M. (1977). Some physiological studies in relation to salt tolerance of Egyptian henbane; Hyoscyamus muticus, L. Ph. D. Thesis, Faculty of

Helaly, M.N.M.; A.M. Salama and A.A. Arafa (1984 a). Effects of salinity on growth, mineral constituents, water fractions and endogenous growth substances in horse been plants. J. Agric. Sci., 9: 251-264, Mansoura Univ., Egypt.

Helaly, M.N.M.; A.M. Salama and A.A. Arafa (1984 b). Effects of some growth substances on growth, certain physiological aspects and yield of fennel plant. J. of Agric. Sci., 9(2): 265-278, Mansoura Univ., Egypt.

Helaly, M.N.M.; S.Z.M. El-Basyouni and A.A. Arafa (1985 a). Physiological studies on salt tolerance in chamomile plant. $2^{\text {nd }}$ Conf. Agric. Botany Sci., 21-24 Sept., 1: 125-148, Mansoura Univ., Egypt.

Helaly, M.N.M.; S.Z.M. El-Basyouni and A.M. Salama (1985 b). Morphological and physiological studies on petunia plants. $2^{\text {nd }}$ Conf. Agric. Bot. Sci. 21-24 Sept. Fac. of Agric. Mansoura Univ. Egypt.

Jackson, M.L. (1973). Soil Chemical analysis. Prentice-Hall of India private. New Delhi, pp. 144-197.

Janes, B.E. (1966). Adjustment mechanism of plants subjected to varied osmotic pressure of the nutrient solution. Soil Sci., 101: 180-188.

Jeffrey, W.D. (1987). Soil Plant Relationships, An Ecological Approch. Groom Helm Ltd., Provident House, Bunel Row Backenham, Kenl BR3 IAT.

Jones, Jr; J. Benton; B. Wolf and H.A. Mills (1991). Plant Analysis Hand book. Methods of Plant Analysis and Inter- pretation. Micro-Macro Publishing, inc., U. S. A. pp. 30-34

Nuttall, J.; R. Armstrong and D. Connor (2003). The effects of salinity, sodicity and soluble boron on wheat yields in the Victorian Southern Malle. Proc. of the 11 Australian Agron. Conference, Geelong., pp. 1-6.

Page, A.I.; R.H. Miller and T.R. Keeney (1982). Methods of soil analysis part 2. Amer. Soc. Agric. Inc. Madison Wig: 595.

Pessaraki, M. (1994). Hand book of plant and crop physiology. New York, Marcel Dekker, Inc. pp 202-381.

Pessaraki, M. (2002). Handbook of plant and crop physiology. New York. Marcel Dekker Inc. pp. 563-581.

Peterburgski, A. V. (1968). "Handbook of Agronomic Chemistry" Kolop publishing House, Moscow. (In Russian) pp. 29-86.

Piper, C.S. (1950). Soil and plant analysis. Inter-Sci. Publ., Inc., New York Univ. Adelaide, Adelaide. 
Helaly, M.N. et al.

Rengel, Z. (1999). Mineral Nutrition of Crops: Fundametal of Mechanisms and Implications. The food products press, Haworth Press Inc., New York. 141-160.

Richard's, L. A. (Ed) (1954). Diagnosis and improvement of saline and alkali soils. Agric. Handbook No. 6, U.S. Dept of Agric.

Salem, S.M.; O.M. El-Shihy; A.M. Ghallab and H.M. Yossef-Ibrahim (2002). Studies on the correlation between resistance against Orobanche and tolerance to salinity in some Vicia faba cultivars. J. Agric. Sci. Mansoura Univ., 27 (7): 4643-4669.

Sharma, S. K. (1995a). Effects of salinity on growth performance and internal distribution of $\mathrm{Na}+, \mathrm{K}+$ and $\mathrm{Cl}$ - in Vicia faba $\mathrm{L}$. Indian Journal of Plant Physiology, 38 (1): 69-72.

Sharma S. K. (1995b). Studies on growth, water relations and distribution of $\mathrm{Na}+$, $\mathrm{K}+$ and other ions in wheat under short term exposures to salinity. Indian Journal of Plant Physiology, 38 (3): 233-235.

Sharma, S. K. (1996). Effects of salinity on uptake and distribution of $\mathrm{Na}+\mathrm{Cl}-$ and $\mathrm{K}+$ in two wheat cultivars. Biologia. Plantarum, 38(2): 261-267.

Taiz, L and E. Zeiger (1991). Plant Physiology. The Benjamin Cummings Publishing Co., Inc. Calif., USA. pp. 195-220.

Vogel, A.L. (1975). A Text Book of Practical Organic Chemistry. Publish by English Language Book Society and Longman Group Limited, 3rd Ed., pp. 197-569,.

Wilkinson, R.E. (1994). Plant Environment Interactions. Marcel Dekker Inc. New York, Hong Kong, pp. 199-245.

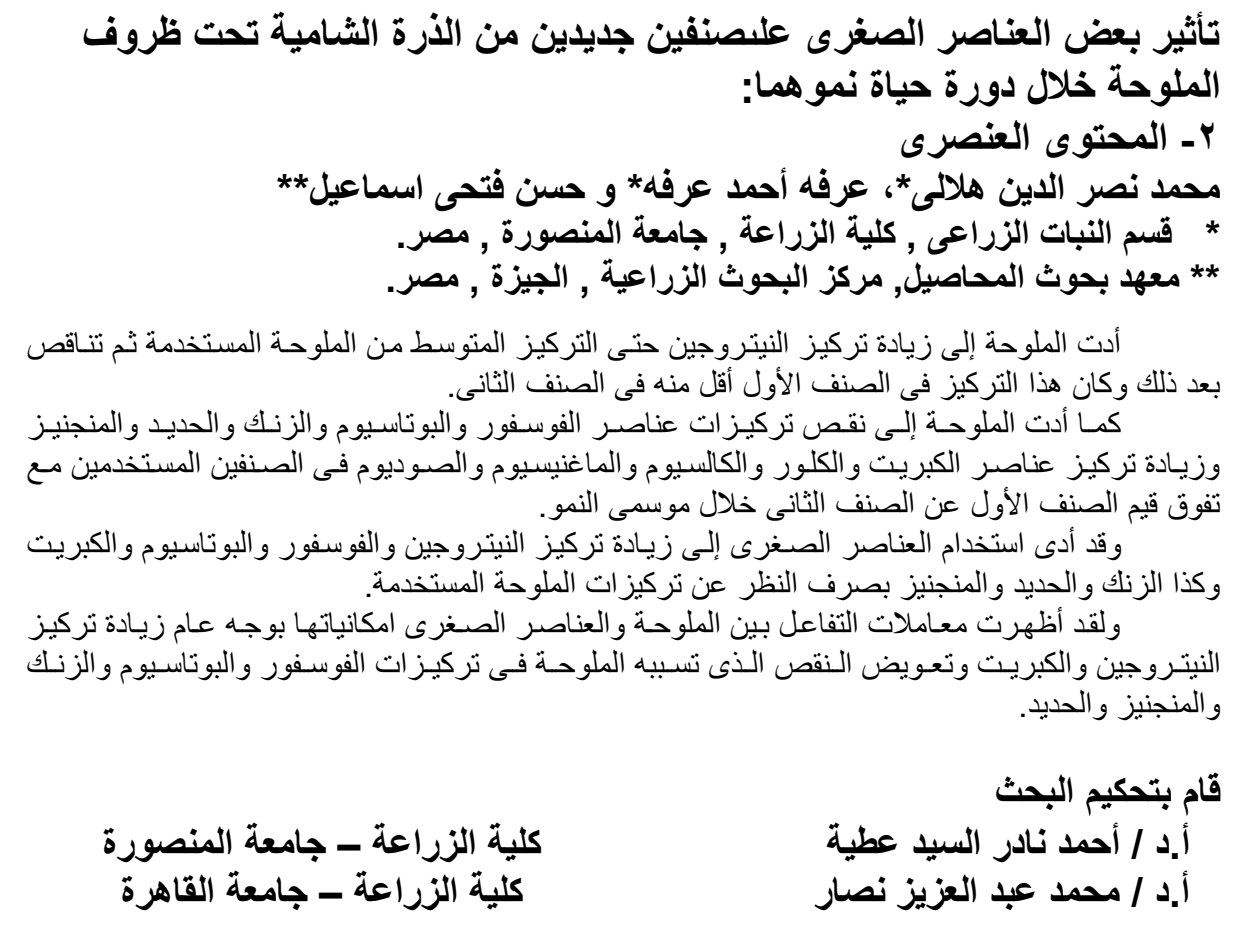


J. Plant Production, Mansoura University Vol.1 (9), September, 2010

1203 